\title{
ARTICLE
}

\section{Law Schools and Ethics of Democracy}

\author{
Special Issue on Pragmatism and Legal Education \\ Sanne Taekema \& Thomas Riesthuis (eds.)*
}

Michal Stambulski**

\begin{abstract}
Contemporary critical analyses of legal education indicate that legal education is undemocratic as it is based on a discipline that produces subjects who obey hierarchies, are free from the habit of criticism and are ready to self-sacrifice for promotion in the social hierarchy. At the same time, critical analyses offer the very passive vision of the law student as merely 'being processed' through the educational grinder. Paradoxically, in doing so they confirm the vision they criticize. This article argues that, by adopting a pragmatic philosophical perspective, it is possible to go beyond this one-sided picture. Over the past few decades, there has been an increase in 'practical' attitudes in legal education. Socrates' model of didactics, clinical education and moot courts are giving rise to institutionalized ideas as structural elements of legal education, owing to which a purely disciplinary pedagogy may be superseded. All these practices allow students to accept and confront the viewpoints of others. Education completed in harmony with these ideas promotes an active, critical member of community, who is ready to advance justified moral judgements, and as such is compliant with pragmatic ethics of democracy.
\end{abstract}

Keywords: legal education, democracy, pragmatism.

\section{Introduction}

A review of contemporary critical analyses of legal education indicates that legal education is perceived as undemocratic, in the sense that it is one-sided, requiring the abandonment of social values and based on accepting arbitrary power. This kind of education produces lawyers who obey hierarchies, are free from the habit of criticism and are ready to self-sacrifice for promotion in the social structure. At the same time, critical analyses offer the very passive vision of the law student as merely 'being processed' through the educational grinder. Paradoxically, in doing so they

* This article was written under National Science Centre, Poland grant, reg. nr. 2015/17/N/HS5/00733.

** Dr. Michal Stambulski is postdoctoral researcher at the Erasmus University Rotterdam and assistant professor at the University of Zielona Gora. 
confirm the vision they criticize. Ultimately, the student can only accept or rebel against the educational authority. His/her agency is therefore very limited and based on a simple choice. This article argues that, by adopting a pragmatic philosophical perspective, it is possible to go beyond this one-sided picture.

In the pragmatic philosophical perspective, adopted here in the version presented by and based on the works of John Dewey, problems of cognition are closely related to problems of desired political organization. Cognition is a type of action, and each action takes place as an exchange (dialogue) between individuals and their environment. That is why every action is conditioned socially, whether it is a scientific or a political one, and every agent (subject of cognition) has the potential to influence their environment. Education can be seen as a process of integration of the individual agent with his/her environment, which at the time of the difference in value between the participants of this exchange creates conflicts. Therefore, the way this process is organized becomes a key issue. In pragmatism, the horizon for actions is the notion of democracy, which here means not only a mode of political organization but also an ethical ideal. The ethics of democracy can therefore serve as a normative point of reference for critiquing educational organization and practices. A democratic society develops democratic and critical individuals who have the capacity to take viewpoints and confront other members of the community peacefully. This allows for an understanding of others: the very understanding that, in the fundamental issues of the life and the shape of the public sphere, someone has the potential to partially de-escalate conflicts by transforming potential wars into conflicts and disputes. The law plays an important role in this process. Therefore, lawyers should have this democratic ethos.

In pragmatism, desired change cannot come from outside, but must be based on existing institutional solutions. Over the past few decades, there has been an increase in 'practical' attitudes in legal education. Socrates' model of didactics, clinical education and moot courts are giving rise to institutionalized ideas as structural elements of legal education, owing to which a purely disciplinary pedagogy may be superseded. All these practices allow students to accept and confront the viewpoints of others. They are focused on the need to argue their position, which forces them to consider counterarguments, promoting a concept of the law in its social context and teaching cooperation. These practices may be completed in a gradual manner. The low level of their completion is an explanation for why the present model of legal education is evaluated so critically. Education completed in harmony with these ideas promotes an active, critical member of community, who is ready to advance justified moral judgements, and as such is compliant with pragmatic ethics of democracy.

\section{Criticizing Legal Education}

In 2018, Samuel Moyn published in The Chronicle of Higher Education a widely commented essay called Law Schools Are Bad for Democracy. Moyn, himself a law teacher and scholar at Yale University, argues that law schools 'whitewash the grubby scramble for power' (Moyn, 2018). According to Moyn, legal education should not only teach future generations the craft of being a legal professional but should also 
address issues of politics and social justice. In Moyn's opinion, at present law schools do not fulfil this purpose - dominated by the logic of the market, they foster an attitude of 'doing well' economically but not 'doing good' ethically and politically. This leads to disappointment for students who expect learning to be involved not only in the affairs of their clients but also of those of justice and the public interest. The result is tension in the consciousness of students between professed values (the struggle for a more just world) and the effects the knowledge they obtain leads to (reproduction of social hierarchy). Moyn asks rhetorically, 'What if the truth of law schools is that their main social function, aside from producing the next round of elites, is that they buy off those who initially doubt that perpetuating elites is what law schools ought to be doing?' (Moyn, 2018). This is due to the fact that law schools give illusions of fighting for social justice (e.g. in law clinics) while reassuring students that lawyers are the main addressees of their statements and the main authorities of the legal universe. Students learn the law and its argumentation, because in every case judges must be persuaded. Others, such as citizens or lawmakers, remain out of the picture. Ultimately, such an education privileges only the legal point of view, which prevents major systemic changes. We can summarize Moyn's arguments by saying that there is too much law and not enough democracy in law schools.

Moyn's argument fits in with a much older and broader criticism of legal education from Critical Legal Studies movement. In a classic 1982 article, Duncan Kennedy forcefully pointed out for the first time on such a scale that the main goal of legal education is the ideological training of obedience to the existing social hierarchy (Kennedy, 1982). Learning the law is learning a new language. The legal language is technical and requires a lot of effort to master. At the same time, it is not a politically neutral language: there is a whole range of views, mostly conservative, on the appropriate economic and social solutions behind it. During their education, students more or less consciously internalize these views. This is facilitated by disciplinary pedagogy: learning a large number of rules by rote, learning to work under stress, adjusting your opinion to the expectations of the lecturer, etc. Although students themselves find this mode of study boring and pointless, it has a social significance. Such a pedagogy leads to the creation of an obedient juridical subject ready to sacrifice for promotion in the hierarchy. According to Kennedy, there is a direct link between legal education and the way lawyers participate in the public sphere. The novice of law has no influence on what they will learn, and discovers at the same time that a legal professional has no influence on the law they apply. One may ask: Is the price to be paid perhaps the alienation of legal professionals? A subordinated legal professional, who claims that law is something external to them, is unable to perform the role of an operator of such law or its translator for public opinion. Not to mention that such an education may tame sensibility, which is understood as the ability to assume the perspective of the other to whom a legal decision relates. A legal professional who was only a subject of processing during the educational process may treat others in a similar way, taking a higher position in a hierarchy.

Another critical theorist, Pierre Schlag, considered the impact that legal education has on the intellectual life of future lawyers (Schlag, 2007). Schlag, similarly to 
Moyn and Kennedy, stresses that law studies are juristocentric, that 'law school teaching is organized around review, dissection and assimilation of judicial opinions' (2007, 575). This practical determination has three important dimensions. Firstly, it translates into the need to memorize a large amount of material, which creates the readiness to perform nonsensical activities. Secondly, the only path ahead for a law graduate is to practice law as determined by corporations. Other activities, such as strategic litigation for the public good, are available to a few. Thirdly, students are taught that their individual choices do not have important consequences and that they should believe in institutions. Taken together, these three dimensions of education reduce the cognitive and intellectual capabilities of future lawyers. They also influence their ethical attitudes. Students learn to accept and submit to 'organized nonsense', which means acceptance of the arbitrary nature of the law and its dependence on the whims and interests of power.

The approach represented by Moyn, Kennedy and Schlag is representative of the important, critical current of reflection on legal education. Even though this critique accurately describes the ideological dimension of legal education and indicating the compromises that must be made by students who want to succeed in the legal world, it adopts a very passive and one-dimensional vision of law schools. The role of the student is reduced to a confrontation, lost from the start, with the educational system, which is subordinated to the needs of governmental and corporate organizations. The only way out of this defeat is to adjust and affirm existing hierarchies or give up participation in the legal world. There is no place for creative action in this hierarchical system. This applies to both teachers and students. Criticism of this type completely ignores the experience of agency that characterizes law students and teachers. It is at best an illusion to sweeten the process of subordination. Such a line of thought strengthens the vision of a student-passive entity that is subject to 'processing' during legal education. The problem is that such a vision is something that - according to the assumptions of this type of criticism should be opposed. That is why, in the end, paradoxically, this type of argument strengthens the vision of subjectivity and interpersonal relationships it was meant to criticize. The way out of this deadlock is to appreciate the democratic potential of law schools and the interactions that take place there. The perspective that allows us to see this potential is philosophical pragmatism.

\section{Pragmatism and Education}

Pragmatism is an internally varied tradition of modern philosophy with a rich history. For a starting point, it is enough to accept that pragmatism sees close links between knowledge and action. Knowledge is never just passed on as an object, but its development and transfer always take place within interactions. For example, the pragmatist and philosopher of education John Dewey pointed out that even a one-sided, informative and disciplinary way of teaching in which the student is treated as an object teaches something more than dry knowledge (Dewey, 2004, 144). During such an educational process, the student learns at least that somebody assumed that what is learned is worth it. Values are transmitted that a student can respond to by internalizing or rejecting them. Keeping one's distance, 
merely instrumentalizing one's education, and pretending to be interested offer tactics that law students can use, and which critical theory seems to omit. In other words, compromising can also be creative.

As indicated by the Polish philosopher Hanna Buczyńska-Garewicz, the main idea of pragmatism is 'solving a philosophical problem of relation between thought and action based on the thesis on the normative nature of cognition' (Buczyńska-Garewicz, 1970, 5). Pragmatism does this through emphasizing the practical nature of every human activity. Cognition is not a reflection of independent reality, but a tool of adjusting and influencing the changeable environment. The relationship between the subject of cognition and reality is local, dynamic and historical the subject is created in and influences the social and political environment in which they live. So, knowledge does not so much represent external reality but rather is a generalization of previous experience and anticipation of future experience, while general ideas are only a way of organizing experience and, as such, are subject to change with it. Knowledge is always contextual, as an external, 'divine' point of view on reality does not exist. Taking this into consideration, the interest of pragmatists moves from fixed and abstract statements about reality towards observing daily, local practices. Each activity, theoretical or practical, is an answer to specific human needs. Specifically, daily practical situations are genetically and structurally primeval in respect of grand theories.

The consequence of this is the recognition that reality is co-created by human activity. This has two important consequences for theoretical reflection. The first concerns the status of theorems - are they descriptive or normative? Reality is not permanent, but depends on human actions in particular situations. Every situation is open, in the sense that the subject-actor has many possibilities of action. Taking one action makes it impossible to take another. Therefore, each action is connected with a choice, which is made because of some values (the actor chooses an action and applies some criterion). Thus, the reality that a human subject experiences is a consequence of their actions and as such is imbued with values. The fact/value dichotomy is therefore not metaphysical in nature, but can at most be a useful tool to organize experience (Määttänen, 2015, 68-70). Here comes the second consequence for theoretical thinking - every description can change into evaluation, so from where can we draw our criteria for assessing reality? What would be a valid normative point of reference for inquiry? The answer of pragmatism is that the community should promote vital values that enable and facilitate further acting. Acting is oriented towards still further actions. The variety of possible actions increases the choice of actions and thus allows us to act more effectively. The preferred actions are those which pave the way to further activity. Pragmatism therefore appreciates pluralism. The notion of pluralism combines individual action with political structure - democracy is a political equivalent of epistemic pluralism. Having that in mind, we may distinguish the following features of philosophical pragmatism: (1) there are no absolute truths (only useful ones); (2) knowledge is contextual (historical, cultural, social and political); (3) the best way of verifying is via experiment; (4) democracy is rooted in daily life and is considered to be the best political system. 
Pragmatism can be seen not only as a philosophy but also as a social theory. The individual is shaped by a continual exchange with the social environment. This exchange is dialogical in nature. George Herbert Mead indicated that the individual self is created in the process of play and game (Mead, 1972, 152-163). These activities require taking a role. Play is based on assuming the role of an individual person (or animal), while games are more rules-oriented. The game requires the point of view of other players. The game is a social situation in which a point of view that connects the whole community emerges, which Mead describes as 'generalized other' (Mead, 1972, 154). The community is based on rules that are depersonalized, so that the same social roles are performed by different individuals. Leszek Koczanowicz rightly points out that the description of socialization proposed by Mead has an ethical dimension (Koczanowicz, 2015, 12-13). Adopting the roles of the others may be based on myriad attitudes and oriented towards many goals. It can be instrumental, based on the willingness to use others, or empathic, oriented towards the willingness to cooperate. The attitude that will be promoted is at least partially determined by the social environment in which the game takes place. This applies in particular to educational organizations and institutions.

One of the most interesting applications of pragmatism's ideals in the research area of social and political organizations was carried out by Philip Selznick. Since it is practices that create reality (and individuals), we can discover the principles governing social life by observing the patterns of these practices. Practices are developed and maintained in communities. That is why Selznick made an important distinction between the concepts of organization and institution. All relatively permanent forms of human association are economic and adaptive (Selznick, 1948). On the one hand, they are a way of managing and distributing resources. On the other hand, they provide communities with the opportunity to manage a changing external environment. Organization is therefore a definition of a social system in terms of purpose and instruments, indicating the objectives to be achieved by this mode of association. It differs from an institution in that the latter is directed not so much towards a technical goal as towards the realization of socially important values (Selznick, 1992, 230-241). Institutions are organizations that are 'saturated' with values. This indicates that institutions are not based on binary logic, but are gradual, and can implement their declared values to varying degrees. The distinction between organizations and institutions can be seen empirically and methodologically. In the former case, it will mean an evolutionary transition from a set of rules and people aimed only at achieving a certain goal to a community connected by shared values. Although it will be difficult to point out the exact moment, it seems that there is a certain threshold of saturation at which an organization becomes an institution. In a methodological sense, this distinction implies two ways of studying human associations. In the first one, aimed at studying organizations, we will be interested in reconstructing the basic structures, goals and available resources of such a system. In the second sense, concerning the study of institutions, the reconstruction of the organization will lead us to reconstructing the basic values that the system embodies and promotes.

It follows from the above that human cognition is practical and always takes place under specific historical circumstances. Since the human self is created in 
interactions that always take place in a particular community, here a question arises about the element linking cognition and community. The answer that pragmatism gives will point to education. Now let's think about the law in a very broad philosophical and social sense. Knowing the law is clearly a practical activity, because knowing the law is at the same time knowing the correct rule for action and being able to make judgements based on it. The community of lawyers is organized - there is a division of labour, a way of distributing social resources and tasks to be fulfilled. This community is also institutionalized - its primary value is justice. What allows a legal community to last and what equips a lawyer with the necessary schemes of action is legal education. Education is a process within the legal world during which the future lawyer is socialized, that is, fundamental values and legal techniques are internalized. On one side of this process is the individual, and on the other side the community. Since legal education plays such an important role, looking at this education will reveal something important about the entire legal world and its values. Therefore, from a pragmatic perspective, legal education, as a research area, is not merely one of the many spaces for the social functioning of law, but becomes one of the most important sources of law, a methodologically and organizationally separate space of its social ontology.

\section{Ethics of Democracy}

The above considerations were descriptive, but the philosophy of pragmatism includes not only a description of cognition and socialization but also normative arguments in favour of a society open to a multitude of possible perspectives (democracy), whose actions resemble what science does (inquiry). Hilary Putnam observed that pragmatism is related to an open society that is pluralistic and tolerant (Putnam, 1995, 57). Pragmatism may come into existence when pluralism is deemed a value and not a sign of decay of social unity.

Using Selznick's concepts, we may see democracy as both an organization and an institution. In the latter, democracy is not only a manner of organization for making political decisions but also an ethical ideal. It assumes an obligation of taking responsibility for public affairs, which in turn leads to an obligation of conscious participation in the public sphere. John Dewey opposed the vision of democracy as a simple form of government in which an aggregate of individuals makes political decisions and elects representatives (Dewey, 1997). Such 'quantitative' optics do not tell us much, except for indicating the fragmentary nature of a democratic government, which may be seen as a source of weakness of this political form. Democratic fragmentation may prolong the political decision-making process and make it unsatisfactory for all parties involved. This approach ignores the fact that the source of democratic authority is not a simple number of individuals. According to Dewey, the source of authority lies in laws understood as constitution, institutionalized values being the basis of a political body. People are not isolated atoms, but parts of a greater social whole which they co-create and which co-creates them. Therefore, the very act of democratic voting may be perceived as an act of self-cognition and self-determination of community. Each single vote is then an expression of social tendencies (desires, aspirations and goals) which the 
voting process and the public connected with it facilitates, meliorates and projects onto the community as a whole. The close dialogical dependence between the individual and society makes democracy not only a political ideal but also a 'way of life' (Dewey, 1998, 341).

Considering the pragmatic philosophy of politics, Leszek Koczanowicz observes that democracy is a particular form of binding the individual with society (Koczanowicz, 2011, 99). From the point of view of the society, democracy is a space that ensures individual autonomy and multiple opportunities for acting. From the point of view of the individual, democracy is a lifestyle and an ethical commitment. Both perspectives are mutually conditioned. Koczanowicz notices that politics in democracy is based on the tension between the unfulfilled ideal of full democracy (values), daily political practices (democratic habits) and institutions. This triad is a useful tool for analysing laws, which may also be analysed with regard to an ideal contained in them, their daily functioning and the institutions guarding them. Koczanowicz indicates that what combines these perspectives is imagination understood as the ability to question, criticize and reconstruct the existing reality, and also the ability to formulate alternatives rules for acting. The work of imagination should be done by activity with the capacity to observe the internal rules of this world and to link them.

In the pragmatic perspective, the manner of acting of an individual-subject in the democratic environment is similar to scientific acting. It is an entire process, which Dewey termed 'inquiry' (Dewey, 1938). Inquiry consists in transforming an undetermined situation into a determined one. It is, like political activity, solving specific problems. Human acting is deliberate and during its performance encounters obstacles which require the person (or group) to engage in problematization of the situation itself: perhaps the means to an end was selected badly; maybe the very end was selected incorrectly. If, after a change, acting fails to encounter any further obstacles, then the subject repeats it in similar situations until they encounter subsequent obstacles. A previously efficient rule determines future actions. It creates a series of actions based on analogy. Each action is based on this general scheme, including scientific action. A subject creates and then tests hypotheses in the conditions of an experiment. An unsuccessful experiment demands that we review hypotheses which are again subjected to evaluation. The success of scientific research consists in creating new knowledge understood as 'warranted assertibility' (Dewey, 1938, 7; 1941, 180-182). The theory of inquiry leads to two conclusions: there is no strict distinction between theory and practice, and only real problems are important. Acting is directed by previous theories - so they are of a practical nature. Practice, in turn, helps to verify theory - by directly impacting it. Doubts, in turn, occur only when obstacles are encountered. It is the situation and direction that dictate the conditions of criticism, and not thinking itself. Charles Sanders Pierce discussed this in the context that 'genuine doubt' demands causes (Hildebrand, 1996). Doubts are only philosophical if resolved intellectually and have practical consequences for the social world. In the case of genuine doubts, the mode of solving them affects the rules adopted as the basis for further action in the world. 


\section{Democratizing Legal Education?}

Behind pragmatism stands a clear vision of education which may be used for research, evaluation and designing a model of legal education. In this perspective, knowledge is a social value, and it is of a democratic nature. It is not that knowledge should be subjected to a procedure of democratic voting, but that if knowledge is always of a hypothetical nature it should be questionable, and such claims may be made by anyone. So, education should not be oriented at transferring information, which can be falsified at any time, but rather at equipping with the skills necessary for acting. People are social beings who develop themselves thanks to interactions with others. Educational practices intentionally use this social condition of individuals. A critical attitude to existing categories and notions, openness to other points of view, anti-dogmatism, a sense of autonomy and readiness to make judgements (Nowak, 2013, 26-27) are the skills which should characterize a good student as well as a good citizen. The skills and intellectual attitudes necessary to act are at the same time the skills and attitudes of a citizen in a democratic society.

Let's now take a more normative look at legal education and try to answer the question of how it can respond to contemporary criticism. A traditional perspective would demand the construction of a theoretical model of the notion of law and then adjustment of curriculum to it. This would imply a dilemma: more theoretical subjects (philosophy, history, sociology of law) or practical ones? Legal education would be limited to the transfer of relevant knowledge or skills. Pragmatism breaks with such an attitude, indicating that it is the way of coming to knowledge that is more important that the contents of that knowledge - it has to be based on openness to experimental verification of hypotheses in order to overcome existing obstacles. We have already indicated that such a scheme of action is also characteristic of a democratic community. Pragmatism notices a deep analogy between scientific inquiry and democratic practice. If democracy is a 'way of life', then democratic potential is universal and thus has to be contained in the institutional infrastructure of the educational process experienced by future legal, especially that the education of a critical and pro-democratic citizen is an official objective of university legal education and a point of reference for its criticism. Naturally, legal education may be considered in the background of higher education, and the democratic nature of this education will then depend on general barriers of access to higher education. If students are excluded from law school due to high tuition fees and the lack of a realistic support system of scholarship, then already at the starting point the democratic horizon gets narrowed - social and class homogenization deprives the student of the opportunity to meet with others. The same holds if education excludes the possibility of discussion. Domination of lectures, single choice tests and lack of influence on the management of campus do not allow the teaching of a democratic ethos. These, however, are structural factors, which relate to all higher education. What is interesting here are the purely legal factors characteristic of law schools. Finding such features of this education, and then verifying them with regard to the ethics of democracy, would enable us to answer the question about the democratic potential of this education. 
It seems that we may distinguish at least three ideas that have determined discussions on legal education for decades. They are: the Socratic model of education, law clinics and moot court. I am interested in them as certain ideal types, and the following considerations relate first of all to what we could call their philosophical, values-oriented contents. In this sense we could call those ideas 'institutions' in the Selznickian sense.

Despite the increasing importance of other, more innovative methods, the Socratic method remains, next to the teaching lecture, one of the main methods of legal education (Abrams, 2015). The Socratic method has a form of dialogue based on asking questions. Partners in this kind of dialogue are teacher (questions) and students (answers). When students hear a counterargument, they must react. Socratic dialogue may be a method of manipulation under which an ironic interlocutor is forcing the other side to adopt a determined role (Brickhouse \& Smith, 2009, 179). It may be, however, an opportunity to seriously test hypotheses. A difference results from whether an interlocutor is really willing to change roles. Then this method is 'a rich, subtle, complex and powerful epistemological process for obtaining knowledge' (Conry \& Beck-Dudley, 1996, 378).

Application of the Socratic method in law schools is related to the postulate of formulating justifications of legal decisions. Legal professionals, and in particular judges, in systems based on the rule of law should justify their decisions so as to inform a citizen how a decision has been reached, and in particular, which laws were applied and how the facts were reconstructed (Lyons, 1984, 193-199). In the pragmatic perspective, public justification creates the possibility to question it. The legal system copes with this through a system of appeal and the possibility of challenge. Through the Socratic method, students are taught to justify their own position and evaluate and question the roles of others. The duty to formulate justifications supports the integration of the student with the social role of a lawyer. The ability to challenge such a justification and subject it to rational criticism promotes the need to adopt the role of the other because of the necessity to take into account any possible objections beforehand.

If teaching by the Socratic method takes place mainly in lecture halls and seminar rooms, law clinics work outside the simple 'learned-taught' pattern. Law clinics are a programme, completed in some law schools, consisting in rendering legal services such as legal advice or writing simple official papers for citizens by students. Such programmes have been developed globally since the 1960s (Giddings, $2008,2-4)$. The name of the 'clinic' suggests analogies with the teaching of doctors, for whom performing therapeutic activities during training provides the necessary experience. Nowadays, as a rule, legal clinics serve people who cannot afford professional legal assistance. At the level of professional preparation, thanks to participation in law clinics, students obtain skills useful in their future work in law firms, such as the ability to speak with a client, the possibility to conduct one's first case and improve one's ability to write legal papers. At the level of interactions in a law clinic, students go outside their typical environment and meet people from outside their class or cultural community. There exists a danger of adopting a hierarchical attitude to the client of the law clinic, which is based on expert distancing. The situation itself, however, creates the possibility to adopt a different role, a view on 
a world of ordered legal rules from the perspective of a person subjected to these rules who, for various reasons, is unable to cope with them on their own. Also, the very idea of law clinics is justified by the public responsibility of legal professionals - if they have knowledge which enables them to act efficiently and justifies their social prestige, this knowledge should be used for the benefit of the community, and in particular for the benefit of marginalized groups. Not every student has to participate in a law clinic - its existence itself is a message for promoting voluntary public commitment.

In law schools, moot court is one of the forms of activity outside the curriculum and consists in simulating a court trial. Under preparations for moot court, students analyse a case, prepare their role and then present it in public in the conditions of a simulated court trial. At the professional level, participation in moot court develops the skills of performing legal research, preparation of a role and public speaking. Moot courts are at the same time 'clinical and academic' (Gaubatz, 1981, 89). It is important that it is a group activity - cases that students resolve are so complicated that they demand cooperation. In fictitious proceedings, these groups compete with each other. When preparing for moot courts, students learn to cooperate and compete with one another. On the one hand, it forces them to work out the rules of the division of labour. On the other, it forces them to adjust to the rules of competition.

The institutions of the Socratic method, law clinics and moot courts are based on the activation of a student who cannot be restricted to a passive transfer of knowledge. Adopting such optics leads to subjectify a novice in law, who should actively participate in the process of education and not be merely its passive object. These rules are also of a formal nature. They do not determine what should be taught with their use. In this sense they remain open, and even democratic.

What these educational institutions have in common is that they are practically oriented but do not deny the need for theoretical reflection - in this sense, we can say that they are pragmatic. In his classic article on the need for practical education in law schools, Jerome Frank pointed out that such education is closest to what a lawyer actually does. Without this, students who only learn from books are like 'architects who study pictures of buildings' (Frank, 1933, 912). The value of this type of teaching lies in the fact that it shows that the law is not only a structured system of rules, but usually operates through disputes and conflicts. The concept of law which results from this approach is argumentative and social; law is perceived not as recreated but as co-created by legal professionals in a continuous process of communication and conflict. At the same time, law appears as a tool for problem-solving and adaptation. It is something that may be questioned and something that evolves. Law's status becomes similar to that of a scientific hypothesis in the pragmatic perspective. As long as it helps to cope with a situation, it is useful. The need for revision appears when a problematic situation occurs, and it demands a review of previous assumptions until a new rule is created that will combine the maximum possible compliance with previous hypotheses and highest possible efficiency in the face of a novel situation.

It should be clear that the institutions of legal education reconstructed in this manner contain democratic potential. The idea of education resulting from these 
institutions is based on an active subject who participates in the legal world to which he/she is trained. Giving justifications for one's role and the readiness to change it in the event of better arguments, the ability to adopt another role and others' perspective, working out and adjusting to the rules of cooperation in order to achieve an assumed objective - these are competences which should characterize a democratic personality. Moreover, it is commonly agreed that developing these competences should be the purpose of legal education.

\section{Conclusion}

Only through participation in democratic practice can one obtain democratic competences and ethos. If we accept that openness, readiness to make and justify moral judgements, ability to adopt a different viewpoint are democratic virtues, then each education should develop these virtues, and legal education in particular. After all, the law has an important role as a tool of human communication and a mediator of conflicts.

Socratic questions, the dedication of one's time and knowledge to help others solve conflicts in which they are involved, the possibility of cooperation and competition with others, adopting a different point of view are guiding ideas of modern legal education. All this supports the democratic ability to assume the role of the other. These ideas, however, are scalable. We may risk the hypothesis that if these ideas are maximized, then legal education will appear as involving and developing, and when these ideas are fulfilled only to the bare minimum, education will become boring and stupefying. This has important consequences for the role of law in a democratic society. Law schools developing democratic ethos in students make legal professionals feel responsible for law and more involved in their community, which enhances and legitimizes the legal system. Law schools based on arbitrary hierarchies alienate legal professionals from society, which effects the delegitimization of the legal system.

The ideas of justification of decisions, cooperation and adoption of the perspective of the other, institutionalized in legal education, may constitute a 'foothold' for analyses of legal education. Such research should aim at indicating to what extent and in what specific institutions these ideas are made whole. Such analyses are simultaneously descriptive and normative: descriptive as they may limit themselves to the statement that the ideas are fulfilled or not and indicate reasons for such status; normative as they may indicate what should be changed to fulfil the ideas to a greater extent. Much may be said about democracy as a 'way of life' and an ethical ideal, but not that it is boring.

\section{References}

Abrams, J. M. (2015). Reframing the Socratic method. Journal of Legal Education, 64(4), 562585.

Brickhouse, T. C. \& Smith, N. D. (2009). Socratic teaching and Socratic method. In H. Siegel (Ed.), The Oxford handbook of philosophy of education. Oxford University Press. 
Buczyńska-Garewicz, H. (1970). Wartość i fakt: rozważania o pragmatyzmie. Państwowe Wydawnicttwo Naukowe.

Conry, E. J. \& Beck-Dudley, C. L. (1996). Meta-jurisprudence: The epistemology of law. American Business Law Journal, 33, 373-450.

Daly, Y. M. \& Higgins, N. (2011). The place and efficacy of simulations in legal education: A preliminary examination. All Ireland Journal of Higher Education, 3(2), 58.1-58.20.

Dewey, J. (1938). Logic. The theory of inquiry. Henry Holt.

Dewey, J. (1941). Propositions, warranted assertibility, and truth. The Journal of Philosophy, 38(7), 169-186.

Dewey, J. (1997). The ethics of democracy. In L. Menand (Ed.), Pragmatism: A reader (pp. 182204). Vintage.

Dewey, J. (1998). Creative democracy - The task before us (1939). In L. A. Hickman \& T. M. Alexander (Eds.), The Essential Dewey (pp. 340-343). Indiana University Press.

Dewey, J. (2004). Democracy and education. Aakar Books.

Frank, J. (1933). Why not a clinical lawyer-school? University of Pennsylvania Law Review and American Law Register, 81(8), 907-923.

Gaubatz, J. T. (1981). Moot court in the modern law school. Journal of Legal Education, 31(1/2), 87-107.

Giddings, J. (2008). Contemplating the future of clinical legal education. Griffith Law Review, 17(1), 1-26.

Grossman, G. S. (1974). Clinical legal education: History and diagnosis. Journal of Legal Education, 26(2), 162-193.

Hildebrand, D. L. (1996). Genuine doubt and the community in Peirce's theory of inquiry. Southwest Philosophy Review, 12(1), 33-43.

Kennedy, D. (1982). Legal education and the reproduction of hierarchy. Journal of Legal Education, 32(4), 591-615.

Koczanowicz, L. (2011). Etyka demokracji. In L. Koczanowicz (Ed.), Lęk nowoczesny. Eseje o demokracji i jej adwersarzach. Universitas.

Koczanowicz, L. (2015). Politics of dialogue. Non-consensual democracy and critical community. Edinburgh University Press.

Lynch, A. (1996). Why do we moot? Exploring the role of mooting in legal education. Legal Education Review, 7(1), http://www.austlii.edu.au/au/journals/LegEdRev/1996/3.html.

Lyons, D. (1984). Justification and judicial responsibility. California Law Review, 72(2), 178199.

Määttänen, P. (2015). Mind in action: Experience and embodied cognition in pragmatism. Springer International.

Moyn, S. (2018). Law schools are bad for democracy, The Chronicle of Higher Education, https://www.chronicle.com/article/law-schools-are-bad-for-democracy/.

Nowak, E. (2013). Demokracja zaczyna się w umyśle. Rozwijając osobowość demokratyczną. Principia, (57-58), 23-40.

Putnam, H. (1995). Pragmatism. An open question. Blackwell.

Selznick, P. (1948). Foundations of the theory of organization. American Sociological Review, 13(1), 25-35.

Selznick, P. (1994). The moral commonwealth: Social theory and the promise of community. University of California Press.

Singer, B. J. (1999) Pragmatism, rights and democracy. Fordham University Press.

Sullivan, M. (2007). Legal pragmatism. Indiana University Press. 